Kapata Arkeologi, 13(2), 209-222

ISSN (cetak): 1858-4101

ISSN (elektronik): 2503-0876

http://kapata-arkeologi.kemdikbud.go.id

\title{
REVITALISASI KEBINEKAAN MELALUI KAMPANYE SLOGAN ARKEOLOGIS HASIL PENELITIAN SITUS KOTA CINA
}

\section{Diversity Revitalization with Archaeological Slogan Campaigns from the Research Results of Kota Cina Sites}

\author{
Defri Elias Simatupang \\ Balai Arkeologi Sumatera Utara - Indonesia \\ Jl. Seroja Raya, Medan 20134 \\ difrai_simatupang@yahoo.co.id
}

Naskah diterima: 03/09/2017; direvisi: 02/10 —22/11/2017; disetujui: 23/11/2017

Publikasi elektronik: 30/11/2017

\begin{abstract}
This paper discusses the diversity of Indonesian people that needs to be improved following more susceptible of conflict in the communities with different ethnic, religion, race, and class. The archaeological research institution should be able to contribute for this process by using the research result of the Kota Cina in Medan North Sumatera. One of the approach which can be adopted is the use of arcaheological slogan. These slogans can be produce by using the parameter analysis of measureable mass communication with the content analysis method. The observation shows that the archaeological slogan of the Kota Cina can be produce and contribute to deliver the message in order to revitalize the diversity.
\end{abstract}

Keywords: diversity, slogan, archaeological

\begin{abstract}
Abstrak
Tulisan ini membahas kebinekaan masyarakat Indonesia yang semakin rentan menghadapi ujian dan tantangan seiring semakin berkembangnya teknologi informasi. Institusi penelitian arkeologi sudah sepantasnya mampu memberikan kontribusi melalui hasil penelitian dalam hal ini Situs Kota Cina di Kota Medan Sumatera Utara. Dalam upaya merevitalisasi kebinekaan, hasil penelitian Situs Kota Cina diangkat sebagai bahan kampanye slogan arkeologis. Slogan-slogan arkeologis hasil penelitian Situs Kota Cina dibuat berdasarkan kajian paramater pengamatan komunikasi massa yang terukur dengan metode analisis isi. Dari hasil pengamatan, slogan arkeologis hasil penelitian Situs Kota Cina dapat dibuat dan diyakini mampu berkontribusi menyampaikan pesan dalam usaha merevitalisasi kebinekaan, dengan catatan yang harus diperhatikan menyangkut penguasaan materi seputar hasil penelitian Situs Kota Cina.
\end{abstract}

Kata kunci: kebinekaan, slogan, arkeologis

\section{PENDAHULUAN}

Bineka adalah keranekaragaman, beragam, bermacam-macam, dan sebagainya. Kebinekaan merupakan keanekaragaman yang sangat tampak (Kamus Besar Bahasa Indonesia, 2013: 194). Berdasarkan riwayat sejarah, kebinekaan Indonesia adalah karunia yang tidak bisa ditolak. Tetapi dibalik itu, tersimpan potensi konflik disebabkan perbedaan latar belakang suku, agama, ras, golongan, dan kelas ekonomi. Untuk dapat menghilangkan potensi konflik, perlu usaha meningkatkan komunikasi antar kelompok yang melewati sekat-sekat perbedaan itu. Dengan komunikasi yang baik, dapat mendukung terbentuknya model-model interaksi sosial yang mengakui dan mengagungkan perbedaan dalam kesederajatan secara individual, maupun sosial. Model-model ini sebenarnya telah digunakan sebagai acuan para pendiri bangsa dalam mendesain kebinekaan melebur menjadi satu yang dinamakan sebagai kebudayaan bangsa, sebagaimana yang terungkap dalam Pasal 32 UUD 1945, yang berbunyi: "kebudayaan bangsa (Indonesia) adalah puncak-puncak kebudayaan di daerah." Masalahnya puncak kebudayaan di daerah sarat akan pemaknaan subjektifitas yang 
tinggi di tengah-tengah masyarakat yang majemuk. Derrida dalam Sutrisno menyatakan kalau kemajemukan adalah kebebasan mengeksplorasi realitas yang membawa keberagaman pemaknaan, tak terkecuali antar kelompok yang berbeda (Sutrisno, 2005: 173174). Maka keberagaman pemahaman kebinekaan suatu bangsa harus dimaknai melalui keberagaman pemahaman riwayat terbentuknya bangsa itu sendiri.

Potensi lunturnya kebinekaan bisa dilihat dari generasi masa kini. Semakin banyak konflikkonflik yang terjadi di masyarakat yang mengusung label solidaritas etnis dan agama tertentu yang sebenarnya tidak perlu terjadi jika pemerintah jeli dalam membaca situasi dan kondisi sosial yang dialami masyarakat Indonesia. Kemendagri mencatat peningkatan adanya paham radikalisme tertinggi pada tahun 2012. Pada tahun 2012, telah terjadi 128 konflik di Indonesia akibat paham radikalisme. Pada tahun 2010 tercatat 93 konflik dan 2011 sebanyak 77 konflik (Assifa, 2013). Angka tersebut tentunya sangat mengkhawatirkan, maka usaha merevitalisasi bukanlah sebuah tawaran lagi terutama di daerahdaerah yang rawan konflik. Pancasila harus kembali disosialisasikan sebagai sebuah ideologi yang diambil dari nilai-nilai luhur budaya dan nilai religius bangsa Indonesia. Ideologi Pancasila bukanlah untuk memperjuangkan kelas atau golongan tertentu (Kaelan \& Zubaid, 2007: 164165). Kebinekaan bangsa Indonesia adalah warisan yang tidak begitu saja diwariskan, tapi harus dikuatkan kembali sesuai dengan kompleksitas problematika kebinekaan masa lalu hingga sekarang.

Revitalisasi merupakan suatu proses atau cara dan perbuatan untuk menghidupkan kembali suatu hal yang sebelumnya terberdaya sehingga revitalisasi berarti menjadikan sesuatu atau perbuatan untuk menjadi vital, sedangkan kata vital mempunyai arti sangat penting atau sangat diperlukan sekali untuk kehidupan (Kamus Besar Bahasa Indonesia, 2013: 1549). Revitalisasi dalam tulisan ini terkait dengan upaya membuat paham kebinekaan yang dianggap semakin luntur pada masyarakat Indonesia kembali menjadi sebuah paham yang sangat penting. Adapun kampanye dipahami sebagai sebuah tindakan yang bertujuan mendapatkan pencapaian dukungan yang dilakukan oleh peorangan atau sekelompok orang terorganisir. Slogan adalah motto atau frasa yang dipakai sebagai ekspresi sebuah ide atau tujuan komunikasi yang mudah diingat. Maka kampanye slogan arkeologis bermaksud memunculkan slogan-slogan yang bersumber dari hasil penelitian rekonstruksi kebudayaan di masa lampau, yang ditujukan untuk kepentingan revitalisasi kebinekaan. Para pelaku (aktivis) revitalisasi kebinekaan biasanya warga negara yang memiliki nasionalisme yang tinggi. Sikap nasionalisme menjadi suatu penilaian atau evaluasi terhadap rasa cinta tanah air dan bangsa atas kesadaran dan tanggung jawab sebagai warga negara. Implementasi nasionalisme diwujudkan melalui: cinta terhadap tanah air dan bangsa, berpartisipasi dalam pembangunan, menegakkan hukum dan menjunjung keadilan sosial, memanfaatkan sumberdaya sekaligus berorientasi pada masa depan, berprestasi, mandiri dan bertanggung jawab dengan menghargai diri sendiri dan orang lain, serta siap berkompetisi dengan bangsa lain dan terlibat dalam kerjasama internasional. Nasionalisme yang ideal ini akan mengantarkan warga negara sebagai orang-orang yang mempunyai kualitas psikologis yang tinggi (Kusumawardani \& Faturochman, 2004: 71). Dengan melakukan usaha revitalisasi kebinekaan, maka akan berbanding lurus dengan membangkitkan nasionalisme untuk sama-sama mempertahankan kedaulatan negara.

Revitalisasi tentunya menjadi usaha yang tersistematis membangun kembali spirit kebinekaan yang terindikasi mengalami kemunduran. Indikasi kemunduran dapat dilihat melalui konflik-konflik kerusuhan SARA yang terjadi sejak dekade tahun 2000an, yaitu kerusuhan Ambon dan Sampit terekspos. Konflik SARA dipandang merupakan konflik yang pelik. Semakin besar perbedaan SARA, semakin dalam potensi konflik yang bisa terjadi, yang pada gilirannya memicu disintegrasi bangsa. Pentingnya revitalisasi kebinekaan dapat diartikan sebagai usaha mengembalikan kepada subjeknya, yaitu sebagai bagian dari semboyan negara yang tertera pada Pancasila (lambang negara kesatuan Republik Indonesia), maka tidak bisa ditawar penggantinya karena dipandang sebagai alat permersatu bagi kebinekaan. Dalam sebuah jajak pendapat yang dilakukan Litbang Kompas (Setiawan, 2011), antusiasme publik untuk mengembalikan Pancasila diungkapkan oleh hampir semua responden, yaitu sebanyak 95,7 \%. Mereka memandang Pancasila perlu dipertahankan keberadaannya sebagai ideologi 
negara. Sebanyak 91,6 \% responden juga masih percaya Pancasila adalah ideologi paling baik bagi bangsa Indonesia.

Bangsa yang besar adalah bangsa yang tidak pernah melupakan sejarahnya. Bangsa Indonesia merupakan negara yang memiliki riwayat sejarah yang lengkap dari zaman prasejarah hingga masa terkini. Maka untuk menumbuhkan jiwa nasionalisme pada generasi muda bisa dilakukan dengan berbagai cara seperti melakukan study tour ke tempat-tempat bersejarah seperti ke Situs Kota Cina. Dalam tulisan ini, hasil-hasil penelitian arkeologis di Situs Kota Cina dikaji ulang untuk melihat adanya pesan-pesan terkait kebinekaan sehingga menjadi semacam amunisi untuk usaha menjadikan kebinekaan menjadi penting (revital) kembali terutama demi generasi penerus bangsa. Sejarah telah membuktikan bahwa munculnya kesadaran kolektif rasa nasionalisme di berbagai wilayah, bukan merupakan sebuah produk dari prinsip nasionalisme primitif yang menggunakan kekerasan atau pemihakan semu karena kesamaan ikatan primordial tertentu, melainkan sebagai sebuah hasil dari pilihan yang rasional untuk bersatu dalam konteks keragaman (Purwanto, 2001: 261). Masalahnya, situasi kondisi anak di masing-masing sekolah tentu tidak sama. Pemberian motivasi oleh guru terkait pentingnya kebinekaan serta motivasi dalam mencintai tanah air bisa hanya sekadar tugas menjalankan tugas mengajar semata. Maka dibutuhkan terobosan, karena mempertahankan kebinekaan masyarakat Indonesia di masa terkini idealnya belajar dari rekonstruksi masa lampau, salah satunya pembuatan pesan-pesan kampanye slogan arkeologis hasil penelitian Situs Kota Cina.

Melalui kajian arkeologi, kebinekaan Indonesia coba dilihat dari objek data arkeologi itu sendiri. Masalah yang diangkat terkait bagaimana usaha para arkeolog menemukan makna dari tinggalan arkeologis dikaitkan dengan kebinekaan. Banyak objek yang bisa menyampaikan pesan tersebut, dalam tulisan ini situs yang akan diangkat adalah Situs Kota Cina. Situs Kota Cina yang terletak di Kota Medan, Provinsi Sumatera Utara dapat juga disebut sebagai kawasan situs, karena luasan wilayah yang mencakup puluhan hektar dengan sejumlah sebaran lokasi temuan. Beragam artefak telah ditemuan sejak penelitian arkeologis tahun 1972. Kawasan Kota Cina merupakan sebuah wilayah yang cukup luas dan secara teratur dimanfaatkan sebagai "pergudangan" pertama yang eksis di pantai timur Sumatera dan didatangi langsung pedagang internasional dari India Selatan, Cina Selatan, hingga Teluk Persia. Bahkan ada yang tinggal lama selama pertengahan abad ke-12 di Kota Cina (McKinnon, 1984: 361-362). McKinnon kemudian menyimpulkan Situs Kota Cina merupakan sebuah bandar perdagangan dan pelabuhan dalam jaringan Asia Tenggara dari abad 12-14.

Berdasarkan data, para peneliti sepakat sejauh ini rentang pemanfaatan Kota Cina di masa lalu pada abad 11 hingga 14 Masehi, kemudian berangsur memudar oleh sebab-sebab yang belum dapat dipastikan (Soedewo, 2012: 81-83). Tinggalan arkeologis seperti keramik dan mata uang logam yang cukup banyak ditemukan selama ekskavasi hingga masa terkini, diperkuat oleh berita catatan dari Cina. Keseluruhan data tersebut memberikan rekaman informasi mengenai kondisi arus interaksi perdagangan barang masuk dan keluar dari situs. Berdasarkan hasil penelitian, diketahui pada masa Dinasti Sung abad 10-12 Cina mulai ekspansif melancarkan ekspedisi dagangnya. Akan tetapi ketika abad 17 terjadi penaklukan Dinasti Ming oleh Dinasti Xing menjadi penyebab utama merosotnya perdagangan internasional mereka secara drastis. Hal ini di perkuat dari data ekskavasi jenis temuan keramik di Situs Kota Cina mengisyaratkan kalau persentase temuan keramik Dinasti Sung-Yuan sangat dominan (Purnawibowo, 2010: 140-143).

Pengaruh hegemoni Cina dalam aktivitas perdagangan di situs Kota Cina dari naik ke masa puncak hingga menurun tentu dapat dilihat pengaruh hubungan antara situasi perpolitikan di setiap wilayah teritorial dengan sistem perdagangan internasional yang dinamis dari masa ke masa. Maka dalam kaitan dengan tulisan ini, merevitalisasi kebinekaan dipandang sebagai upaya mengingatkan agar tidak melupakan sejarah Situs Kota Cina yang 'terganggu' akibat instabilitas salah satu negara pelaku perdagangan internasional, yaitu Cina yang relatif homogen. Dinamika naik turun hingga menghilang dalam sebuah peradaban tentunya menjadi pelajaran berharga bagi masa kini.

Diluar Situs Kota Cina, isu paham kebinekaan melalui situs arkeologis yang masanya lebih tua pernah diangkat. Arkeolog Kasnowihardjo dalam sebuah seminar arkeologi mengatakan bahwa sejak kurang lebih 500 SM kawasan Pantai Utara Kabupaten Rembang, Jawa 
Tengah, khususnya antara Kecamatan Lasem dan Kecamatan Kragan telah diokupasi berbagai ras baik Mongoloid, Australo-melanesian, dan ras lain yang jejak-jejaknya sampai sekarang masih dapat ditelusuri seperti misalnya bangsa Arab, India, dan Pakistan. Diantara mereka ada yang tidak eksklusif mempertahankan kemurnian ras dan suku bangsanya, beberapa diantaranya mampu berasimilasi antara ras satu dengan ras yang lain, bahkan hingga kawin-mawin antar suku bangsa tersebut (Kasnowihardjo, 2015: 15). Arkeolog Truman Simanjuntak juga pernah mengatakan dalam wawancaranya dengan Jurnalis Majalah National Geographic Indonesia, bahwa kebinekaan telah ada di Indonesia sejak masa kehidupan penutur Austronesia yang menghuni sekitar 4.000 tahun yang lalu. Mereka membawa budaya masing-masing ke Nusantara. Lantaran masuknya pengaruh luar yang berbedabeda, perkembangan budaya itu melahirkan kekhasan lokal. Simanjutak mencontohkan, kebinekaan itu muncul dalam unsur-unsur budaya corak tembikar, pembuatan kain dari kulit kayu, dan ragam mata panah. "Faktor-faktor yang mempengaruhi kebinekaan itu ada semua di sini, mulai lingkungan sampai keletakan dan kondisi geografis. Mereka sejak awal beradaptasi dengan lingkungan, menciptakan tampilan yang berbeda budayanya. Ini yang disebut etnogenesis Indonesia" (Thamrin, 2015).

Etnogenesis yang dapat dipahami sebagai proses terbentuknya suatu kelompok etnik atau suku asli, tidak mudah dipahami. Dibutuhkan pemusatan daya dukung untuk mengemas pengetahuan bahwa etnogenesis para penutur Austronesia eksis hingga kini karena keberhasilan adaptasi terhadap lingkungan masing-masing. Perlu penegasan bahwa identitas yang terbentuk merupakan faktor pokok penyatu persatuan mereka ditinjau dari kondisi lingkungan masingmasing sehingga terbentuk identitas mula-mula di daerah baru. Identitas seiring waktu semakin berkembang dan kemungkinan besar tetap berbeda, namun tidak akan menjadi rintangan karena etnogenesis tadi masih relevan. Kebiasaan-kebiasaan asli dari tempat asal masih diwariskan turun-temurun terutama untuk tinggalan artefaktual yang diwariskan memiliki kesamaan nilai dan fungsi sakral ataupun fungsi profan. Begitu juga dengan kebinekaan yang seharusnya tetap relevan di masa terkini hingga ke depan. Hal ini menjadi sebuah kewajiban para arkeolog peneliti Situs Kota Cina untuk turut ambil bagian mengkritisi sejauh mana langkah teknis terukur paham kebinekaan tetap eksis di negara ini. Melalui tulisan ini, permasalahan tersebut dirumuskan dalam kalimat tanya: "Bagaimana merevitalisasi kebinekaan melalui hasil penelitian Situs Kota Cina?"

Tujuan dari penulisan ini adalah untuk memberikan referensi tambahan sebagai sumbangan Ilmu Arkeologi dalam upaya komprehensif merevitalisasi kebinekaan pada masyarakat Indonesia. Sebagai referensi tentu masih perlu penajaman kajian untuk mengukur kadar optimal tidaknya persoalan kebinekaan diselesaikan dari hasil penelitian arkeologi Situs Kota Cina. Sehingga tulisan ini masih tahapan awal mencoba melihat isi, juga sebagai data hasil penelitian Situs Kota Cina, yang bisa digunakan untuk menjawab rumusan masalah.

\section{METODE}

Adapun metode penelitian yang digunakan dalam tulisan ini adalah metode analisis isi. Analisis isi merupakan salah satu metode dalam kajian komunikasi massa. Lewat analisis isi, penulis mempelajari gambaran isi dari karakteristik pesan, dan perkembangannya pada sebuah media. Dalam mengobservasi isi pesan, dibutuhkan teori-teori yang relevan berfungsi mendukung benar tidaknya isi pesan tersebut sebagaimana yang dikatakan Snelbecker (dalam Moleong, 2005: 57) terkait fungsi teori untuk mensistematiskan sejumlah penemuan penelitian agar mendorong pembuatan hipotesis baru yang argumentatif. Maka langkah teknis secara sederhana dijelaskan urutannya sebagai berikut: Pertama, melakukan reduksi data yang diperoleh baik primer maupun sekunder, kemudian ditentukan data atau informasi yang sesuai dengan penelitian ini dengan pengklasifikasian yang ada berdasarkan fokus penelitian. Kedua, dari kompleksitas data yang penting dan relevan tersebut, dilakukan pengklasifikasian data dalam beberapa penekanan sesuai rumusan masalah penelitian. Ketiga, dalam hal ini sengaja dibuatkan dua contoh slogan berdasarkan datadata arkeologis Situs Kota Cina (langkah pertama). Keempat, agar memudahkan melakukan tinjauan kritis menggunakan teori yang relevan untuk mensistematiskan data penelitian, dan menjadi pendorong penyusunan hipotesis.

Dalam mengkaji kedua makna slogan tersebut, menggunakan teori tentang tipe makna 
dari Leech (dalam Sumilat, 2015), yang terbagi kedalam dua makna: 1. Makna Konseptual yang berarti makna sebenarnya atau makna yang menekankan pada definisi makna itu sendiri (denotatif). 2. Makna Asosiatif, yang berarti makna yang lebih dalam tersirat dari makna konseptual. Makna asosiatif terbagi menjadi 6 tipe, yaitu: a. Makna Konotatif, yaitu nilai komunikatif dari sebuah ungkapan yang diacu, melebihi dari makna konseptualnya. b. Makna Sosial Leech, yaitu makna sebuah kata yang menunjukkan lingkungan sosial penggunanya seperti dialek yang menunjukkan asal usul dari si penutur. c. Makna Afektif, yaitu makna yang menggambarkan perasaan pribadi penutur termasuk sikapnya yang berkenaan dengan perkataannya. d. Makna Kolokatif, yaitu mengandung asosiasi-asosiasi dari suatu kata yang muncul dalam lingkungan kata-nya. Kata yang berkolokasi telah memiliki pasangannya sendiri. e. Makna Reflektif, yaitu makna yang muncul dalam makna konseptual ganda dimana pengertian suatu kata membentuk pengertian lain. f. Makna Tematik, yaitu makna yang dikomunikasikan oleh penutur atau penulis dengan cara mengatur pesannya dalam arti urutan, fokus, dan penekanan.

Kedua contoh slogan sengaja dibuat dengan penekanan makna sebenarnya, karena penulis menganggap tingkat pemahaman publik pada umumnya terhadap slogan arkeologis masih rendah. Masyarakat yang berpendidikan sarjana, mungkin paham arkeologi, tetapi target publik yang dituju adalah masyarakat yang masih didominasi oleh masyarakat berpendidikan tidak sampai sarjana. Penggunaan contoh slogan bermakna asosiatif dianggap tidak akan optimal dan tepat sasaran. Hal ini diperkuat dengan penelitian yang pernah dilakukan Yulianti dalam merancang sebuah strategi kampanye slogan sanitasi sehat bagi masyarakat di Surabaya. Faktor target audiens yang dominan merupakan strategi pendekatan kepada masyarakat agar kampanye dapat selaras sehingga dapat berinteraksi lebih maksimal. Pengaruh kultur pada audiens mempengaruhi pemilihan warna serta karakteristik maskot. Selain itu pengaruh kultur juga mempengaruhi bahasa pada sebuah pesan (Yulianti, 2015).

Data yang diteliti dalam penelitian ini adalah data kualitatif hasil penelitian Balai Arkeologi Sumatera Utara sebagai data primer, dan data sekunder, yaitu tinjauan pustaka dan sumber di internet yang bisa dijadikan referensi alat kampanye merevitalisasi kebinekaan. Dibutuhkan wawasan arkeologis yang kuat dalam memilah pesan tersebut karena berasal dari data ekskavasi arkeologis. Setelah itu dilakukan

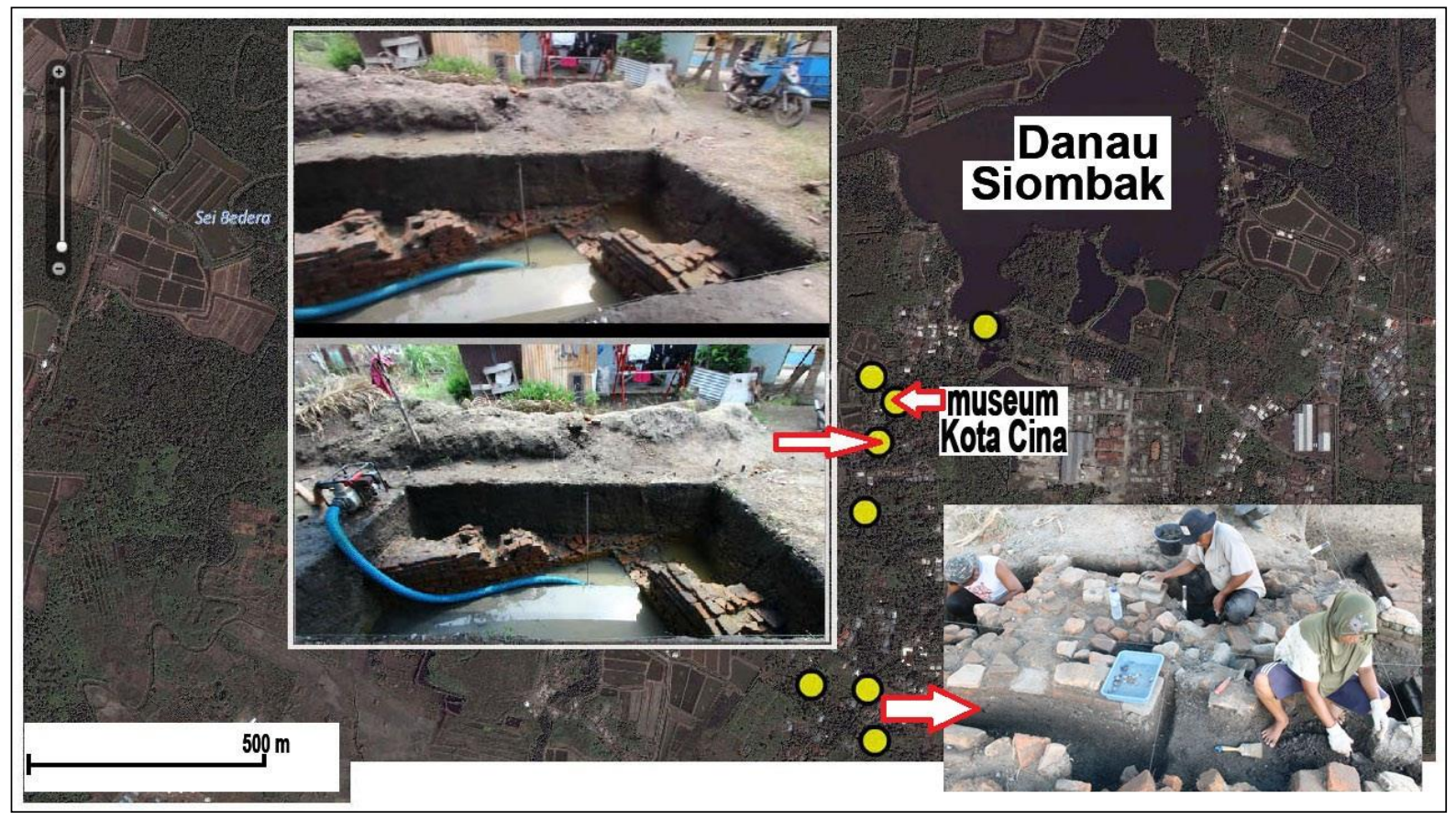

Gambar 1. Peta keletakan kawasan situs Kota Cina (bulatan kuning) yang sudah diekskavasi Balai Arkeologi Sumatera Utara

(Sumber: Peta Google Earth, dan dokumen gambar Balai Arkeologi Sumatera Utara, 2016) 
pemilahan pesan-pesan yang dianggap mengandung pesan efektif "kebinekaan" kepada publik. Hal ini penting untuk membangun komunikasi strategis antara arkeolog sebagai penyampai pesan kajian budaya materi (komunikator) dengan publik sebagai penerima pesan hasil kajian budaya materi (komunikan), dan memberikan respon sebagaimana model komunikasi stimulus-respon (Mulyana, 2001: 143-145).

Penginterpretasian data arkeologis sebagai alat kampanye diharapkan bermanfaat secara teoritis dan praktis dalam penelitian arkeologi publik. Mereka diharapkan dapat memberikan respon dan masukan kepada kalangan peneliti arkeologi (Sulistyanto 2008: 64). Maka kemampuan untuk mengelola kampanye arkeologis membutuhkan kepekaan untuk menemukenali kebutuhan-kebutuhan spesifik yang senantiasa harus ditinjau dan dibentuk kembali. Termasuk pilihan bersinergi dengan institusi pendidikan sebagai bagian dari materi muatan lokal, misalnya bekerjasama dengan sekolah-sekolah di Kota Medan. Kota Medan sebagai wilayah dengan karakter yang juga heterogen dihadapkan pada tantangan serupa. Terdapat kesenjangan terkait pengetahuan sejarah budaya nasional dengan pengetahuan serupa dalam konteks lokal. Menurut Ririmase, ada lima aspek model yang dapat dikembangkan agar kebutuhan sekolah dan peserta didik mendapatkan pengetahuan yang cukup terkait pengetahuan arkeologi sebagai muatan lokal, meliputi: pertama, pengembangan tema konten, kedua, inisiasi model sosialisasi yang lebih interaktif, ketiga, pembaharuan materi, keempat, peningkatan frekuensi, dan kelima, pembinaan tenaga guru. Kelima aspek ini tentu saja dapat diperluas sesuai kebutuhan sekolah dan peserta didik. Harapannya tentu saja agar pengembangan pengetahuan arkeologi sebagai muatan lokal ini mampu menjadi wahana bagi perluasan wawasan dan pengenalan warisan budaya yang menjadi landasan bagi minat generasi muda dalam turut melestarikan warisan budaya nasional (Ririmasse, 2014: 21).

\section{HASIL DAN PEMBAHASAN}

Sebagaimana yang dijelaskan dalam metodologi penelitian, dalam tulisan ini sengaja dibuatkan dua contoh slogan arkeologis yang bersumber dari penelitian di Situs Kota Cina. Amanat yang hendak disampaikan melalu slogan adalah untuk memahami kebinekaan, maka rangkaian kata-kata terpilih bermaksud mengajak, sebagai contoh: "mari kita," "selamatkan," "lestarikan," dan sebagainya. Kalimat dalam slogan diupayakan tidak panjang, yaitu maksimal dua kalimat. Kalimat pertama berisikan ungkapan atau pernyataan terkait data hasil penelitian arkeologi di Situs Kota Cina. Data tersebut harus memiliki kandungan pesan terkait rekonstruksi kebinekaan yang terjadi. Kalimat kedua berisikan ungkapan atau pernyataan terkait ajakan untuk melakukan sesuatu sesuai pesan kalimat tersebut. Kalimat pertama dan kedua tentunya harus bisa terkait satu sama lain. Kalimat kedua adalah pesan utama sedangkan kalimat pertama sebagai pesan penjelas atau penguat dari kalimat kedua. Dalam tulisan ini kalimat kedua pada kedua slogan disamakan, yang berbunyi: "Mari Kita Selamatkan Situs Kota Cina.”

Contoh pertama slogan arkeologis dari Situs Kota Cina berbunyi: "Temuan Mata Uang Tiongkok di Situs Kota Cina menunjukkan keberagaman masyarakat telah terjadi di Kota Medan 800 tahun lalu. Mari Kita Selamatkan Situs Kota Cina." Slogan ini pada dasarnya mencoba mengangkat sudut pandang temuan arkeologis mata uang tiongkok sebagai alat tukar perekenomian masyarakat sudah eksis di Kota Medan sekitar 800 tahun yang lalu. Tentu menjadi sebuah hal menarik ketika alat tukar asing sudah eksis di Kota Medan 800 tahun yang lalu. Apakah ini menunjukkan adanya toleransi siapa dan apa yang berpengaruh pada masa itu? Memang sejalan dengan mulai dikenalnya transportasi air maka perdagangan sudah menjangkau ke tempat-tempat lain yang terpisah oleh lautan atau sungai. Letak geografis kepulauan Indonesia yang menguntungkan menjadikan kepulauan Indonesia sebagai salah satu rute pelayaran perdagangan internasional. Perdagangan sangat dipengaruhi komoditas dagang apa yang penting masa itu, salah satunya yaitu lada sebagai objek buruan dagang internasional yang melimpah di Sumatera. Menurut catatan Marsden, keberadaan lada menyebabkan orang Inggris membentuk permukiman di wilayah pesisir Sumatera di abad ke-17 (Marsden, 2013: 151). Tentu permukiman yang terbangun adalah atas seizin bangsawan setempat. Pada masa itu, mata uang mulai diciptakan dan digunakan sebagai alat tukar di Nusantara.

Mata uang itu logikanya baru diciptakan sejak terjadi peristiwa jual beli yang semakin 
rumit. Kemajuan melakukan transaksi perdagangan internasional dalam catatan Marsden di Sumatera pernah terjadi di Kerajaan Aceh abad ke-17. Mata uang menjadi penentu utama ukuran barter emas dan perak, bahkan menentukan para pedagang internasional dimana mereka bisa berdagang (Marsden, 2013: 483-484). Aspek yang dapat dipahami dari kehadiran mata uang tidak hanya aspek ekonomi, juga aspek politik dan sosial. Kemampuan mereka mengatur pedagang asing tentunya karena kesadaran pentingnya berelasi dengan orang asing. Sangat logis bila hal itu juga diterapkan oleh penguasa Situs Kota Cina pada masa jauh sebelumnya. Sejalan dengan meningkatnya kebutuhan, perdagangan internasional di pesisir pantai timur Sumatera tidak terelakkan. Interaksi manusia yang berbedabeda terjadi karena setiap orang pada dasarnya tidak hanya membutuhkan satu jenis barang melainkan berbagai macam barang, seperti beras, garam, gula, minyak, dan sebagainya. Ketika timbul masalah kalau berdagang dalam jumlah besar, apalagi nilai suatu barang tidak sama dengan barang lain, maka fungsi penguasa lokal akan dominan menentukan. Apabila tidak ditentukan oleh penguasa lokal, berarti sama saja terjajah di wilayah sendiri. Tentu sejatinya pedagang tidak mungkin membawa angkatan perang yang lebih banyak dibanding penguasa setempat. Ada kemungkinan para pedagang membawa mata uang sebagai alat tukar perdagangan.

Perjalanan sejarah mata uang di Indonesia relatif panjang, yaitu meliputi kurun waktu sekitar 15 abad. Pada masa klasik Hindu-Buddha di abad ke-5 sampai abad ke-15, mata uang yang digunakan adalah potongan emas dan perak yang diberi cap sebagai tanda benda itu sebagai alat tukar. Tetapi jaman keemasan kerajaan Majapahit pada abad ke-14 justru yang dominan beredar adalah mata uang tembaga atau kepeng Cina dari berbagai dinasti. Pada masa Islam, mata uang yang beredar selain terbuat dari tembaga dan timah, ada juga yang terbuat dari emas. Mata uang tersebut bertuliskan nama-nama penguasa sesuai tempatnya beredar, disini perlu dipastikan apakah nama Kota Cina termasuk didalamnya, karena pada tahun 1292 Seorang pelancong terkenal Marcopolo singgah di bagian Utara Aceh dalam perjalanannya dari Tiongkok ke Persia melalui laut. Ketika singgah di Perlak, Aceh Timur ia menjumpai penduduk yang memeluk agama Islam, dan juga banyak pedagang Islam yang berasal dari India Selatan. Hal ini menunjukkan pada abad ke-13 telah terjadi pertukaran pengaruh agama Islam di daratan sumatera Utara, dan kehadiran para pedagang muslim yang singgah di berbagai bandar dermaga di Sumatera, kemungkinan termasuk melalui situs Kota Cina. Pada masa kolonial mulai diperkenalkan kertas sebagai alternatif mencetak uang karena sisi penghematan dalam pembuatannya hingga kini.

Contoh slogan arkeologis dari Situs Kota Cina yang kedua berbunyi: "Temuan struktur candi dengan arca Hindu dan Buddha, diperkuat data historis sebagai bandar niaga internasional menunjukkan masyarakat beragam telah berinteraksi di Kota Medan 800 tahun yang lalu. Mari Kita Selamatkan Situs Kota Cina." Slogan ini mencoba mengangkat sudut pandang Kota Cina di Kota Medan, selain pernah menjadi bandar internasional (aspek ekenomi), namun sebaliknya ada juga temuan struktur candi (aspek religi). Tentu menjadi sebuah hal menarik, dua aspek ekonomi internasional dan religi dapat berjalan selaras pada satuan waktu tertentu (Utomo, 2012). Keberadaan data arkeologis berupa mata uang dan barang buatan Cina, dan informasi keberadaan kapal-kapal dagang, dapat menjadi indikator adanya sistem perdagangan internasional dalam lingkup sederhana. Ada catatan Cina tentang pengiriman misi dan utusan dari Kompei di pesisir pantai timur Sumatera ke Cina pada abad ke-7 M (Purnawibowo, 2010: 140). Catatan tersebut bisa memunculkan pesan positif kalau interaksi dengan pihak asing telah lama terjadi dan berlangsung lama.

Interaksi sosial yang tinggi juga disebabkan letak strategis wilayah situs menghadap langsung ke Selat Malaka. Selat Malaka merupakan jalur pelayaran utama pedagang sutra Tiongkok sebelum jatuh ke tangan Portugis pada abad ke16. Tidak heran interaksi sosial di Selat Malaka juga berpengaruh dalam memunculkan keramaian di situs Kota Cina. Menurut Soekanto dalam Bungin, interaksi sosial merupakan hubungan sosial yang dinamis menyangkut hubungan antara orang perorangan, antara kelompok-kelompok manusia, maupun antara orang perorangan dengan kelompok manusia. Syarat terjadinya interaksi sosial adalah adanya kontak sosial dan berkomunikasi. Mereka berkomunikasi untuk saling mempengaruhi dalam pikiran dan tindakan (Bungin, 2007: 55). Oleh karena itu, ketika kontak sosial dan komunikasi belum terjadi, para pedagang-pedagang asing yang pernah datang ke 
situs Kota Cina kecil kemungkinan mendapatkan komoditi yang mereka minati seperti lada, cengkeh, pala, merica, kayu cendana, kapur barus, kain katun, garam, gula, gading gajah, cula badak, dan lain-lain. Sedangkan mereka ingin menukarkan dengan barang mereka seperti: kain sutera, kain brokat, yaitu kain sulaman kaya warna, dan keramik. Tentunya sangat dibutuhkan kreativitas berkomunikasi agar bisa terjadinya interaksi sosial tersebut. Apabila salah strategi para pedagang asing bisa dibinasakan oleh penguasa setempat. Namun bila menguntungkan kedua belah pihak, tidak butuh waktu lama ketika dari jauh terlihat kapal dagang asing datang, dan singkat cerita hubungan dagang dengan pihak asing pun terjadi.

Hubungan dengan pihak asing tentu menimbulkan rasa saling toleransi terkait wujud kebudayaan masing-masing, antara lain ide/gagagsan, aktivitas/perilaku, dan artefak. Terkait artefak bisa saja mengalami transformasi sesuai konteks dimensi waktu dan tempat. Bisa saja struktur batu candi di Situs Kota Cina dengan arcanya berbeda dengan di wilayah lainnya. Bahkan bisa saja artefak yang telah mengalami transformasi tersebut tidak diketahui karena toleransi yang tinggi, maka cenderung mengabaikan urusan ritual yang berbeda agama. Sehinggga terbukti di Situs Kota Cina pertama kali tercatat keberadaanya pada tahun 1823 oleh John Anderson. Anderson, atas perintah Gubernur Penang, W. E. Philips, mengunjungi sejumlah daerah di pantai Timur Sumatera Utara untuk melakukan survei politik dan ekonomi bagi kepentingan Inggris. Dalam laporan yang dia tulis, terdapat bagian yang menjelaskan bahwa pada lokasi yang sekarang dikenal sebagai kawasan Kota Cina, terdapat sebuah batu bertulis berukuran besar yang tulisannya tidak dapat dibaca oleh penduduk yang bermukim di Kota Cina (Anderson dalam Purnawibowo \& Koestoro, 2015: 59). Artinya ada kemungkinan sejarah peradaban Kota Cina pada satu masa sesudah 800 tahun lalu mengalami pergantian corak budaya. Dugaaan ini muncul karena masyarakat di masa abad ke-19 tidak dapat membaca batu tersebut sesuai catatan John Anderson. Idealnya ada yang bisa membaca kalau masyarakatnya homogen lintas generasi. Hal ini bisa menimbulkan dugaan, telah terjadi pengelompokan masyarakat yang berbeda namun hidup pada satu masa di tempat yang sama. Toleransi telah membuat masyarakat tidak harus saling mengetahui terkait aktivitas religi yang dikerjakan karena perbedaan religi, namun saling mengetahui apa yang dihasilkan dari aktivitas religi.

Dari kedua contoh slogan, dapat ditarik sebuah pemahaman yang menggunakan pola susunan tingkatan objek visual yang sama. Perbedaan hanya pada masing-masing kalimat, slogan pertama menekankan pada hasil temuan arkeologis yang berhubungan dengan perekonomian, sedangkan slogan kedua menambahkan artefak religi. Penggunaan mata uang Tiongkok dan adanya sisa bangunan candi di Situs Kota Cina, bisa saja menunjukkan unsur keterimaan masyarakat lokal terhadap masyarakat asing atau pendatang baik untuk agama dan perekonomian. Sudah lazim diskusi kebinekaan yang muncul tergambar dari pola interaksi masyarakat beragam yang idealnya akan dikaitkan ke sektor perekonomian. Kebinekaan tanpa dukungan institusi agama cenderung akan sulit menerima dan saling memahami perbedaan yang ditemuinya. Misalkan masa keberadaan percandian Hindu-Budha di Kota Cina diyakini tidak jauh dari masa mulai eksisnya Islam dan pengaruh modal besar para pedagang bangsa Eropa yang beragama Nasrani. Mungkin saja bangunan ibadah selain percandian sudah ada namun menggunakan bahan yang bukan terbuat dari batu. Penekanan pada para pemimpin institusi agama pada masa itu bisa saja diangkat untuk menjadikan pesan menyadari pentingnya pemisahan kekuasaan atau politik dengan sektor ekonomi dan agama. Kalau tidak bisa dipisahkan, maka dapat disinergikan dalam rumah besar stabilitas perpolitikan pada masa itu. Dari kedua contoh slogan, spirit kestabilan perpolitikan juga muncul di masyarakat pada masa itu.

Dengan mengangkat pesan kebinekaan seperti kedua contoh slogan, dibutuhkan pilihan media yang tepat. Bayangkan saja jika publik turut membantu mempublikasikan contoh-contoh slogan tersebut melalui pilihan media yang mereka sukai. Orang lain yang melihat gerakan itu bisa saja turut berkontribusi. Jika kebinekaan memudar, bukan tak mungkin rasa nasionalisme juga ikut teriris. Spirit nasionalisme adalah tataran konsep kebinekaan yang bisa langsung diwujudkan secara teknis. Misalkan multikulturalisme semakin berkembang di Kota Cina setelah semakin ramainya pedagangpedagang dari berbagai belahan dunia datang yang tentunya mereka tidak dapat memaksakan kebiasaan masing-masing termasuk dalam hal 
interaksi saat makan satu meja (lihat gambar 2). Hal ini dapat dikritisi karena perbedaan mereka adalah sebuah fakta yang hadir supaya mereka mendapatkan pemahaman mencari "keuntungan bersama" dari perbedaan mereka. Perspektif poskolonial sebagai salah satu kajian menegaskan pentingnya untuk menimbang ulang paradigma tentang klaim kebenaran peradaban yang bersifat universal, bukan di monopoli Barat seperti yang terjadi selama ini. Peneguhan konsep "tinggi/pusat" dan "rendah/pinggiran" yang dihegemonikan Barat, sudah seharusnya kita kesampingkan dalam bingkai kesadaran kultural, sehingga kebudayaan dan kebangsaan sebenarnya adalah konsep yang terbuka. Potensi ketidakstabilan budaya dan identitas dalam globalisasi, akhirnya membawa kepada pemahaman bahwa kebudayaan dan identitas merupakan pertemuan dan percampuran berbagai kebudayaan dan identitas yang berbeda-beda (Kasiyan, 2003: 80). Kebudayan dan identitas yang berbeda tentu berpeluang menghasilkan kepentingan yang berbeda pula. Dalam satu kajian lain untuk mengetahui potensi dan kebijakan pengelolaan konflik antar pemangku kepentingan di kawasan Kota Cina pada masa terkini, menunjukkan adanya kesamaan kebutuhan yang menjadi simpul konflik, yaitu penggunaan lahan.

Berdasarkan analisis yang dilakukan terhadap pengampu kebijakan, diketahui bahwa simpul konflik terletak pada penggunaan lahan untuk kebutuhan hidup manusia dan pelestarian sumber daya arkeologi Situs Kota Cini itu sendiri. Cara mengelola konflik yang dilakukan adalah melalui negosiasi. Negosiasi dapat diwujudkan dalam bentuk musyawarah untuk menghasilkan kesepakatan bersama. Pada kesepakatan itu diberi porsi atau peluang kepada masyarakat sebagai salah satu pengampu kebijakan dalam pengelolaan kawasan Kota Cina terkait dengan penilaian, harapan, dan persepsi masyarakat terhadap Situs Kota Cina sebagai tinggalan arkeologis. Dalam hal ini, arkeolog dan pemerintah berperan sebagai fasilitator dan pengontrol pelestarian sumber daya arkeologi tersebut. Dalam pengelolaan dan pelestarian kawasan Kota Cina sebagai Cagar Budaya, masyarakat diharapkan memiliki peran dan sikap positif karena ada keterkaitannya dengan pemenuhan kebutuhan hidup mereka sehari-hari. Karena pemilik kebudayaan adalah publik, pelestariannya pun harus muncul dari publik itu

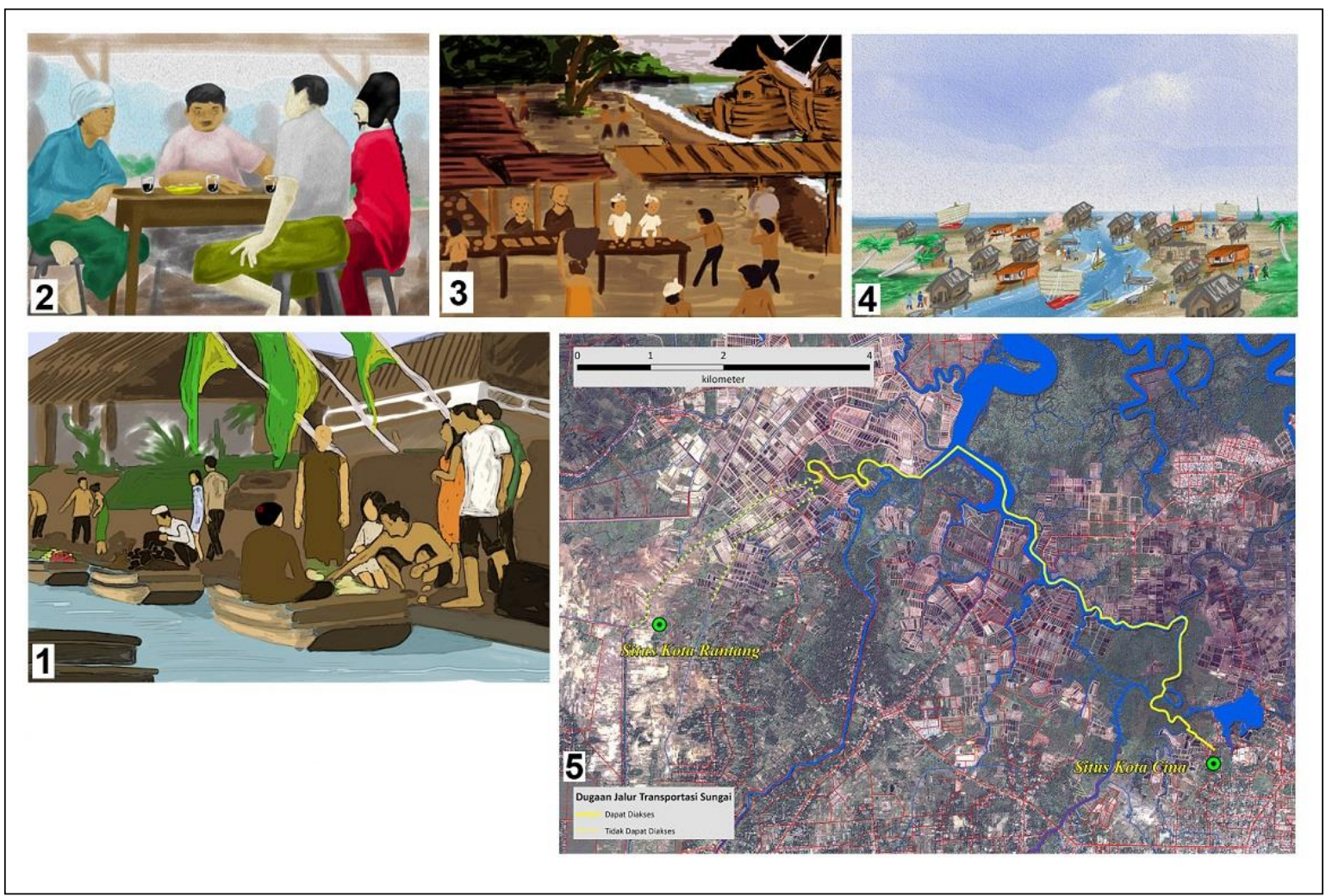

Gambar 2. Beberapa ilustrasi gambar yang direkonstruksi terkait keberadaan Situs Kota Cina (ilustrasi 1-4) dan peta jalur perairan Situs Kota Cina hingga menuju utara Belawan (5)

(Sumber gambar: Balai Arkeologi Sumatera Utara) 
sendiri. Di pihak lain, peran pemerintah lebih difokuskan pada penyiapan regulasi atau peraturan, baik dalam bidang pelestarian, pengembangan, maupun pemanfaatan Cagar Budaya (Purnawibowo \& Koestoro, 2016: 78). Disinilah permasalahan selanjutnya muncul ketika kebinekaan itu sendiri bila diangkat publik perorangan, justru bisa berpotensi membuat salah persepsi terkait kesadaran kepentingan yang berbeda-beda sehingga pemerintah "wajib" mengakomodir berbagai kepentingan tersebut.

Kebinekaan dalam perspektif kebudayaan menunjukkan bagian dari tujuh unsur universal kebudayaan meliputi: bahasa, sistem peralatan dan teknologi, sistem mata pencaharian, organisasi sosial, sistem pengetahuan, religi, dan kesenian. Kebinekaan masuk kategori sistem pengetahuan yang bertransformasi menjadi produk-produk kebudayaan material yang nantinya dipelajari oleh manusia-manusia lain tanpa berinteraksi langsung dengan si pembuatnya. Maka sistem pengetahuan terhadap kebinekaan dalam perspektif kebudayaan tidak mutlak diwariskan secara generatif (biologis), bisa diperoleh dengan cara mengadopsi hasil-hasil perwujudan gagasan dan aktivitas manusia masa lalu yang meliputi: kebudayaan materiil, yaitu sistem peralatan dan teknologi, dan Kebudayaan non-materiil, yaitu sistem pengetahuan. Misalkan kampanye slogan sebagai propaganda dibuat hanya untuk menguntungkan si pembuat kampanye. Namun apakah kampanye itu justru merugikan pihak lain? Kalau tidak ada yang dirugikan, tetapi jusru menguntungkan pihak lain yaitu bangsa lain yang ingin belajar, ketika melihat Bangsa Indonesia berhasil menjaga kerukunan rakyatnya yang beraneka ragam maka itu menjadi sebuah prestasi. Namun harus diakui, manusia pada umumnya memiliki sikap curiga dalam merespon setiap aksi yang diidentikkan sebagai kegiatan kampanye.

Kecurigaan publik terhadap kegiatan kampanye Situs Kota Cina bisa muncul akibat masih kurangnya membangun komunikasi stimulus-respon. Para arkeolog diharapkan mampu mengenali genius kebudayaan Indonesia di sepanjang perjalanan sejarahnya, sehingga dapat memberikan sebuah pengetahuan lebih tentang nilai-nilai luhur yang ada pada masa lampau, dan kontekstual di masa kini (Restiyadi, 2009: 6). Jangan sampai terjadi miskomunikasi pada masyarakat Situs Kota Cina yang pada masa terkini mungkin sudah tidak memiliki nilai-nilai luhur yang ditinggalkan, karena mereka yang tinggal sekarang adalah para pendatang. Konflik terjadi karena pihak-pihak yang terlibat mempunyai tujuan yang berbeda. Konflik bisa juga terjadi karena cara untuk mencapainya berbeda, meskipun tujuan yang berkonflik sama (Wirawan, 2010: 8). Sebagai contoh, potensi perebutan lahan ekonomi Situs Kota Cina yang dianggap 'basah.' Masyarakat yang sudah tinggal lama di daerah setempat akan memiliki tingkat kecurigaan dari siapapun yang datang ke kawasan mereka. Miskomunikasi yang berujung konflik dapat terjadi dari maksud orang luar datang untuk mengangkat harkat mereka justru dianggap hendak 'menguasai tanah mereka.' Menurut Lee dalam Yudohusodo (1998), pergerakan masyarakat umumnya akan sangat keras bila dikaitkan persoalan kepemilikian tempat tinggal. Mereka akan berani 'menabrak aturan' berdasarkan siapa yang lebih dahulu menempati, bukan siapa yang memiliki surat tanah (Yudohusodo, 1998: 63-64).

Untuk meredam miskomunikasi, manfaat kampanye slogan arkeologis harus dilihat bukan hanya dari motif keuntungan komersial sebagai permintaan sistem ekonomi pasar di masa kini. Strategi penanaman paham kebinekaan memang sedari awal membutuhkan kajian yang mendalam sebelum dikampanyekan. Bukan berhenti mengkaji sebelum kampanye, dan melanjutkannya setelah memiliki dana yang direncanakan. Kebinekaan yang di kampanyekan merupakan sebuah kesadaran program yang vital. Jangan sampai dipandang sebagai muatan negatif untuk kepentingan individualis. Contoh kedua slogan yang dibahas memiliki motivasi yang mengangkat isu hasil penelitian arkeologi yang tidak dapat diklaim sebagai transaksi kepentingan individualis-ekonomis. Kegiatan ekonomi masa lampau menunjukkan paham bahwa kelas ekonomi tingkat atas idealnya memiliki paham wawasan kebinekaan yang lebih tinggi, melihat kelas dibawahnya sebagai objek pemenuhan kebutuhan sosial mereka sebagai sesama warga negara. Dalton dalam Sairin (2002) menyatakan kalau transaksi ekonomi masyarakat masa lampau tidak hanya mengejar standar nilai ekonomisnya tetapi juga pemenuhan nilai sosial, yaitu penghargaan antar pelaku ekonomi (Sairin et al., 2002: 42-43).

Dari kedua contoh slogan, hal utama yang harus diingat adalah pesan visual yang diyakini mudah ditangkap publik. Kedua slogan dapat 
disederhanakan lagi dengan ditambahkan pesan visual, misalkan gambar-gambar arkeologis. Penggabungan dengan tulisan menjadikannya bahasa visual. Bahasa visual menghasilkan pesan visual non verbal yang jauh lebih mudah dan cepat disampaikan ketimbang pesan verbal. Sewajarnya pesan visual dapat dikembangkan sesuai dengan pesan yang akan disampaikan. Tentu saja ide-ide visual yang terkandung didalam pesan visual tersebut harus tetap dapat dimengerti secara universal (Kusrianto, 2009: 17-19). Slogan arkeologis Situs Kota Cina harus memberikan efek pesan visual yang pada dasarnya sama dengan efek komunikasi, yaitu mengakibatkan terjadinya perubahan pada diri khalayak atau orang yang mendapatkan pesan tersebut (komunikan). Efek komunikasi dapat berupa feedback (umpan balik). Adapun umpan balik dapat berupa, antara lain: kognisi (penambahan wawasan atau pengetahuan), afeksi (sikap), dan psikomotorik (perubahan perilaku atau perilaku baru). Kognisi diharapkan muncul yang pada akhirnya memunculkan perubahan perilaku baru atas apa yang telah disampaikan oleh komunikator sesuai dengan yang diharapkan (Cangara, 1998: 24-28). Slogan arkeologis Situs Kota Cina tak ada salahnya dibuat secara menyengat, bahkan tidak tertutup kemungkinan terkesan ekstrim. Mengampanyekan slogan arkeologis tentunya terkait dengan tujuan dari aspek aksiologi dari ilmu arkeologi itu sendiri yaitu hasil rekonstruksi yang menjadi dasar kebijakan bagi pemangku kepentingan.

Sederhananya arkeologi mencoba mengkaji fenomena segala perbedaan di masa lalu dengan mencoba mengembangkan pendeskripsian perebadaan-perbedaan itu. Seandainya terdapat paradok di dalam arkeologi, itu bukan karena untuk memicu perbedaanperbedaan tadi, akan tetapi karena arkeologi mereduksi perbedaan-perbedaan tersebut, yang hanya memutarbalikkan nilai yang sudah ada (Foucault, 2012: 304-305). Misalnya masalah peperangan yang menimbulkan korban akibat perbedaan kepentingan perdagangan internasional direduksi demi pembuatan slogan yang lebih berpesan agar terjadinya peningkatan unsur kestabilan dalam terjalinnya toleransi dalam perdagangan internasional di Situs Kota Cina. Kunci terakhir untuk menciptakan slogan kampanye menarik adalah dengan membunyikan pada semua media. Menurut Laswell (1979), media artinya perantara, saluran pembawa pesan disampaikan kepada komunikan (penerima pesan), yang pada akhirnya diharapkan ada umpan balik. Proses berlangsungnya komunikasi instruksional dapat diuraikan sebagai berikut: komunikator, yaitu pemerintah sebagai pengirim

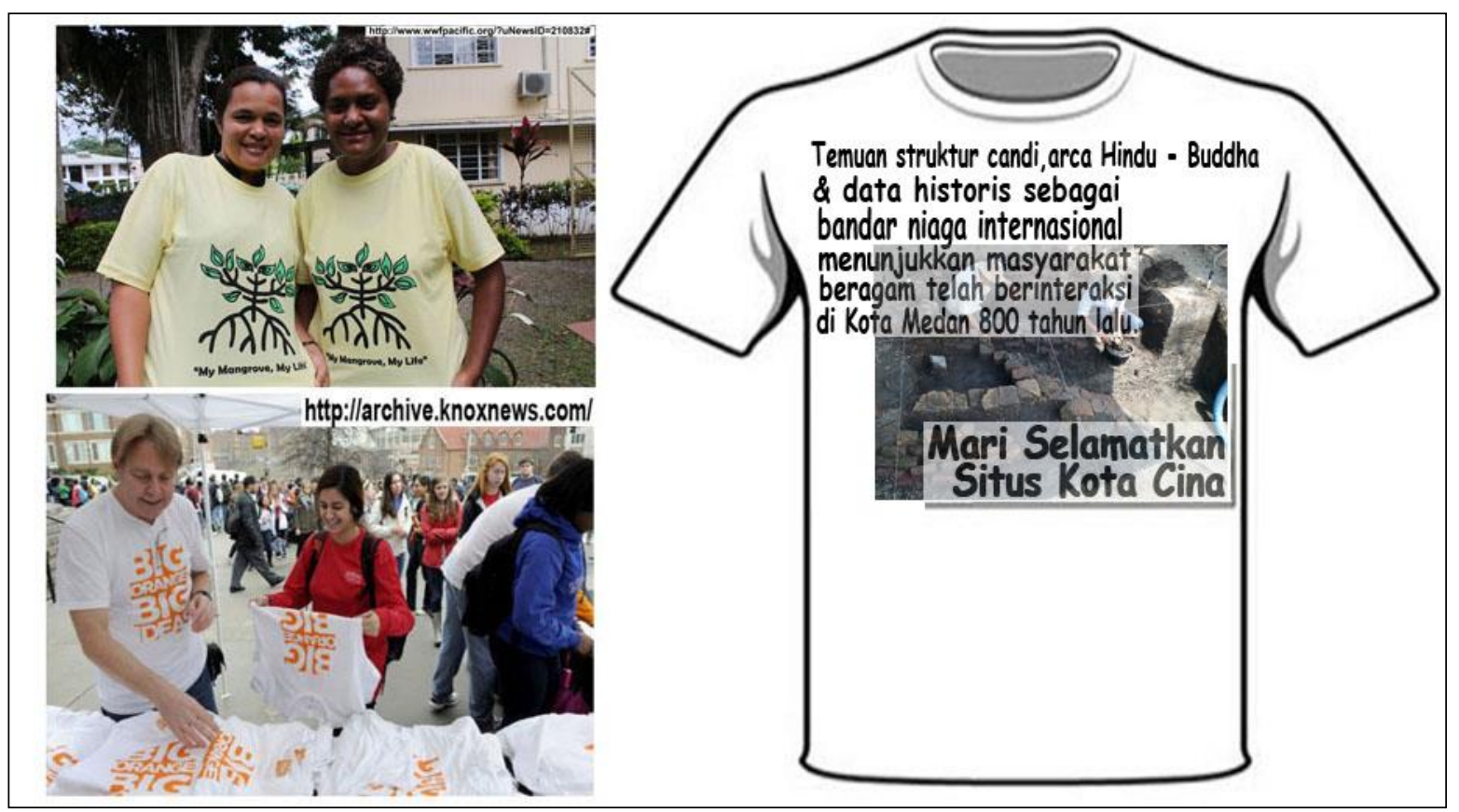

Gambar 3. Beberapa contoh kampanye slogan melalui media sablonan kaos (kiri). Penggunaan media tersebut dapat digunakan dalam kampanye slogan arkeologis Situs Kota Cina (kanan) (Sumber: laman internet tertera pada gambar (kiri), Balai Arkeologi Sumatera Utara (kanan)) 
pesan bermaksud berkomunikasi menyampaikan pesan kepada publik sebagai komunikan. Pesan itu disampaikan melalui suatu media seperti baliho atau media lain baik secara langsung maupun tidak langsung. Pesan yang disampaikan berupa informasi dalam bentuk bahasa atau pun simbol-simbol yang bisa dimengerti oleh kedua belah pihak. Komunikan menerima pesan yang disampaikan dan menerjemahkan isi pesan yang diterima ke dalam bahasa yang dimengerti oleh kedua belah pihak. Komunikan memberikan reaksi atas pesan yang dikirimkan kepadanya, apakah memahami pesan yang dimaksud oleh si pengirim, sehingga diharapkan dengan mudah mengerjakannya dengan penuh kesadaran (Mulyana, 2001: 69-71). Media cetak pada saat ini sudah menjadi bagian besar dari kehidupan sehari-hari, tepat kiranya menggunakan sarana ini sebagai media pendidikan dan penyadaran publik sebagai tujuan poyek ini.

Dalam mengembangkan proyek kampanye slogan arkeologis terkait kebinekaan, sangat penting memiliki rencana yang baik. Strategi perancangan biaya akan sangat mempengaruhi terkait pencetakannya. Perancangan dan persiapan yang baik akan menyelamatkan penghematan waktu dan uang proyek. Komputer dan program-program desain grafis telah membuka dunia baru dalam mengekspresi kreasi dalam mendesain slogan tersebut. Pemikiran penting lainnya adalah sistem produksi yang dipilih berdasarkan kualitas dan kuantitas objek kampanye, misalkan kaos bersablon slogan arkeologis revitalisasi kebinekaan, maka sistem produksi harus menekankan kecukupan anggaran dalam skala waktu yang dirancang. Apabila memungkinkan, coba menggunakan tim kreatif resmi, yaitu pihak ketiga yang berasal dari non pemerintah, karena proyek yang melibatkan partisipasi usaha media publikasi akan membantu menciptakan rasa memiliki dan meningkatkan keterlibatan serta dukungan terhadap proyek ini.

Rencana produksi sampai distribusi kampanye adalah unsur yang sangat penting dalam perancangan program media. Perlu menentukan cara yang terbaik untuk menyampaikan cetakan materi kepada publik yang dituju dengan menggunakan sistem Produksi-Distribusi dengan biaya-biaya yang berhubungan lainnya. Konsep yang kreatif adalah fondasi dari keberhasilan proyek media, maka disediakan waktu untuk memastikan tetap berada di jalan yang benar sebelum melangkah terlalu jauh. Bicarakan ide dengan orang-orang yang menjadi tujuan media. Dibutuhkan kehati-hatian dan lebih kritis dalam memahami makna dari kalimat-kalimat yang menjadi slogan kampanye, perhatikan gaya bahasa yang digunakan dalam slogan-slogan kampanye yang dibuat, apakah slogan itu sesuai dengan kepribadian dan sikapnya atau mungkin slogan itu hanya dibuatbuat hanya untuk menarik simpati dan perhatian publik. Model perancangan slogan kampanye arkeologis terkait revitalisasi kebinekaan sebaiknya didahului penyusunan target publik yang akan merepon secara jelas. Sehingga media cetak yang digunakan lebih efektif.

Misalnya slogan kampanye arkeologis disablon pada media kaos akan menargetkan kawula muda yang fakta pada umumnya lebih banyak menyukai menggunakan kaos dibandingkan tingkat usia lainnya. Tentunya lebih efektif menjadikan kawula muda sebagai target penerima pesan akan revitalisasi kebinekaan. Sebagian besar arkeolog terindikasi jarang mendidik publik kawula muda melalui pesan visual yang tersablon. Para arkeolog lebih bersikap seperti jurnalis ketimbang akademisi dengan cara menjadi pelayan untuk komunitas yang mereka bayangkan. Pemahaman yang lemah dari publik tidak seharusnya direspon arkeolog secara gelap mata, tanpa mengetahui publik yang mana yang diajak berkomunikasi. Karena itu hanya akan menghasilkan 'kebosanan' interpretasi yang tidak tepat sasaran (Merriman, 2004: 8). Namun tidak juga menghindari 'kebosanan' interpretasi dengan cara menyajikan interpretasi liar. Misalnya mempublikasikan temuan-temuan yang kebetulan sadar tidak sadar arkeolog telah mengganti unsur pendidikan menjadi interpretasi masa lalu yang justru berpotensi mengungkap konflik-konflik lama berbau SARA. Sementara interpretasi dasar yaitu fakta kebinekaan di masa lalu dianggap informasi yang biasa, cenderung usang, sudah "membosankan." Padahal ini hanya masalah kemasan penyajian data interpretasi yang bermanfaat bagi kepentingan publik secara umum.

\section{KESIMPULAN}

Merevitalisasi kebinekaan melalui kampanye slogan arkeologis Situs Kota Cina merupakan sebuah keniscayaan. Pembuatan slogan yang memenuhi kaidah ilmiah dan ketertarikan visual, diyakini mampu berkontribusi 
dalam usaha merevitalisasi kebinekaan. Adapun catatan yang harus diperhatikan adalah menyangkut penguasaan materi seputar hasil penelitian Situs Kota Cina. Apabila para arkeolog peneliti Situs Kota Cina menyadari pentingnya mempublikasikan secara sederhana pesan visual dari perkembangan hasil penelitian mereka, misalkan slogan perihal kebinekaan, niscaya Situs Arkeologi dapat diselamatkan dan dikembangkan demi kepentingan publik. Kunci terakhir untuk menciptakan slogan kampanye menarik adalah dengan membunyikannya pada semua media. Masyarakat idealnya diharapkan dapat memaknai kampanye-kampanye slogan arkeologis tersebut lewat pemahaman multikulturalisme yang berdasarkan spiritualitas. Perbedaan adalah bagian tak tergantikan dari sejarah bangsa Indonesia lewat Bhineka Tunggal Ika serta rasa toleransi yang jadi perekat adanya kebinekaan masyarakat. Kebinekaan seni budaya adalah perekat persatuan Indonesia bukan sebagai pemicu adanya konflik antar anak bangsa.

Disarankan agar setidaknya upaya publikasi melalui kampanye slogan arkeologis menjadi salah satu kegiatan yang dapat diprogramkan pada institusi pemerintah. Salah satu tugas dan fungsi Pusat Penelitian Arkeologi Nasional dan Balai Arkeologi Sumatera Utara terkait pendayagunaan dan publikasi hasil penelitian arkeologi, jangan sampai masih sebatas nomenklatur non-substansial. Menciptakan peluang-peluang penyerapan anggaran melalui pembuatan produk-produk publikasi yang berisikan slogan arkeologis yang dikampanyekan tersebut apabila dipublikasikan dengan strategi publikasi yang matang diyakini mampu merevitalisasi kebinekaan dan sekaligus membangkitkan rasa nasionalisme terhadap negara ini atau bisa saja setiap website resmi institusi arkeologi diharapkan memiliki satu konten untuk mampu menampung berbagai contoh desain visual bercorak arkeologis yang dapat digunakan oleh siapapun sebagai kegiatan kampanye publikasi arkeologi untuk kebinekaan Bangsa Indonesia. Pola hubungan antar kelompok institusi plat merah semestinya bukan sebatas kajian yang menghasilkan produk laporan penelitian, tetapi turut melahirkan produk fisik seperti kaos yang berslogan kebinekaan misalnya.

\section{Ucapan Terima Kasih}

Penulis mengucapkan terima kasih kepada pihak-pihak yang telah membantu baik secara langsung maupun tidak langsung hingga banyak data hasil penelitian Situs Kota Cina Kota Medan dapat dimanfaatkan. Penulis juga mengucapkan terima kasih kepada para pembaca yang memberikan masukan baik berupa saran dan kritik untuk perbaikan tulisan ini.

$$
* * * * *
$$

\section{DAFTAR PUSTAKA}

Assifa, F. (2013). Aksi Kekerasan di Indonesia Semakin Meningkat. Harian Kompas Online. Retrieved September 6, 2015, from http://megapolitan.kompas.com/

Bungin, B. (2007). Sosiologi Komunikasi: Teori, Paradigma, dan Diskursus Teknologi Komunikasi di Masyarakat. Jakarta: Kencana.

Cangara, H. (1998). Pengantar Ilmu Komunikasi. Jakarta: Raja Grafindo Persada.

Foucault, M. (2012). Arkeologi Pengetahuan. Yogjakarta: IRCiSoD.

Kaelan \& Zubaid, A. (2007). Pendidikan Kewarganegaraan. Yogyakarta: Paradigma.

Kamus Besar Bahasa Indonesia. (2013). edisi keempat. Jakarta: Gramedia P. U.

Kasiyan, M. (2003). Revitalisasi Dialetika Pluralitas Budaya Global Dalam Perspektif Poskolonial. Jurnal Humaniora, XV(1), 74-82.

Kasnowihardjo, G. (2015). Kebinekaan sebagai Pemersatu Bangsa: Kontribusi hasil penelitian arkeologi, Situs Kubur Prasejarah di Pantura Jawa. In Evaluasi Hasil Penelitian Arkeologi (EHPA)-Semarang. Unpublish work.

Kusrianto, A. (2009). Pengantar Desain Komunikasi Visual. Yogyakarta: Andi.

Kusumawardani, A. \& Faturochman. (2004). Nasionalisme. Buletin Psikologi Universitas Gadjah Mada, XII(2), 61-72.

Marsden, W. (2013). Sejarah Sumatera. Jakarta: Komunitas Bambu.

McKinnon, E. E. (1984). Kota Cina Its Context And Meaning in The Trade of Southeast Asia In The Twelfth to Fourteenth Centuries. Dissertation Cornell University.

Merriman, N. (2004). Introduction: Diversity and Dissonance in Public Archaeology. In Nick Merriman (Ed.), Public Archaeology. London: Routledge.

Moleong, L. J. (2005). Metodologi Penelitian Kualitatif. Bandung: PT. Remaja Rosdakarya.

Mulyana, D. (2001). Ilmu Komunikasi Suatu Pengantar. Bandung: PT. Remaja Rosdakarya. 
Purnawibowo, S. (2010). Jejak Perdagangan Bebas Cina di Situs Kota Cina dan Pulau Kompei. Berkala Arkeologi Sangkhakala, XIII(2), 133144.

Purnawibowo, S., \& Koestoro. (2015). Strategi Pengelolaan Kawasan Kota Cina. Berkala Arkeologi Sangkhakala, XVIII(1), 57-76.

Purnawibowo, S., \& Koestoro. (2016). Analisis Stakeholders Dalam Pengelolaan Sumber Daya Arkeologi di Kota Cina. Amerta, 34(1), 65-80.

Purwanto, B. (2001). Memahami Kembali Nasionalisme Indonesia. Jurnal Ilmu Sosial dan Ilmu Politik Universitas Gadjah Mada, 4(3), 243264.

Restiyadi, A. (2009). Identitas Budaya, Kreativitas dan Kajian Arkeologi Publik. Berkala Arkeologi Sangkhakala, XII(23), 1-7.

Ririmasse, M. (2014). Pengetahuan Arkeologi sebagai Muatan Lokal: Penerapannya di Maluku. Kapata Arkeologi, 10(1), 13-22.

Sairin, S., Semedi, P., \& Hudayana, B. (2002). Pengantar Antropologi Ekonomi. Pustaka Pelajar.

Setiawan, B. (2011). Ideologi Pancasila Bukan Frasa Mati. Retrieved April 13, 2017, from http://nasional.kompas.com/

Soedewo, E. (2012). Obyek-obyek Ideofak dari Situs Kota Cina: Refleksi Kehidupan Religi Penghuninya. Berkala Arkeologi Sangkhakala, $X V(1), 81-98$.

Sulistyanto, B. (2008). Resolusi Konflik dalam Manajemen Warisan Budaya Situs Sangiran. Dissertation Universitas Indonesia.

Sumilat, L. J. (2015). Makna Slogan dalam Iklan Elektronik Berbahasa Inggris pada Majalah Berbahasa Indonesia. Skripsi, Universitas Sam Ratulangi.

Sutrisno, M., \& Putranto, H. (2005). Teori-teori Kebudayaan. Yogyakarta: Kanisius.

Thamrin, M. Y. (2015). Truman Simanjuntak dan Pluralisme Prasejarah Nusantara. Retrieved September 4, 2015, from http://nationalgeographic.co.id/

Utomo, W. (2012). Pecahan Kapal Kuno Ditemukan di Medan. Retrieved September 6, 2015, from http://sains.kompas.com/

Wirawan. (2010). Konflik dan Manajemen Konflik: Teori, Aplikasi, dan Penelitian. Jakarta: Salemba Humanika.

Yudohusodo, S. (1998). Transmigrasi Kebutuhan Negara Kepulauan Berpenduduk Heterogen dengan Persebaran Yang Timpang. Jakarta: JAG.

Yulianti, D. 2015. Perancangan Kampanye Sanitasi Sehat di Surabaya. Jurnal Sains dan Seni ITS, 4(2), 64-49. 